\title{
RED AND BLUE LIGHT-EMITTING DIODES SIGNIFICANTLY IMPROVE IN VITRO TUBERIZATION OF POTATO (SOLANUM TUBEROSUM L.)
}

\author{
Robin Kumar PUNDIR ${ }^{1}$, Abhishek PATHAK ${ }^{1}$, Devanshi Chandel UPADHYAYA ${ }^{1}$, \\ Annamalai MUTHUSAMY ${ }^{2}$, Chandrama Prakash UPADHYAYA ${ }^{1 *}$ \\ ${ }^{1}$ Potato Phenomics Laboratory, Department of Biotechnology, Dr. Harisingh Gour Central University, \\ Sagar, Madhya Pradesh, India \\ ${ }^{2}$ Department of Plant Sciences, Manipal Academy of Higher Education (MAHE), \\ Manipal, Karnataka, India
}

Received: October 2020; Accepted: April 2021

\begin{abstract}
The tuberization phenomenon in potatoes (Solanum tuberosum L.) is a highly synchronized morphophysiological process occurring on the underground stolons under the influence of various intrinsic and extrinsic factors. This involves the participation of the phytochrome sensory system, transport of sucrose from source to stolon, and several regulatory pathways including tuber-inducing hormone biosynthetic lipoxygenase (StLOXI) gene and major calcium-mediated signaling pathway genes ( $S t C D P K$ and $S t C a M 1$ ). This study was aimed to explore the impacts of distinctive qualities of the light-emitting diode (LED) light with a specific wavelength on in vitro tuberization of potato. Single nodal segments of potato 'Kufri Jyoti' were incubated in vitro on the growth medium at a temperature of $22 \pm 2{ }^{\circ} \mathrm{C}$ and exposed to various combinations of red (R) and blue (B) LED light. The results showed that the combination of $30 \%$ red $+70 \%$ blue LED light $\left(\mathrm{R}_{30} \mathrm{~B}_{70}\right)$ significantly shortened the tuber induction period, increased the number of tubers, and their yield compared with these parameters in the tissues exposed to the white light $\left(\mathrm{W}_{100}\right)$. The induction of the in vitro tuberization correlated with the enhanced expression of the major tuberizing pathway genes, including the lipoxygenase (StLOXI), calmodulin ( CaM1), and calcium-dependent protein kinase (StCDPK). The current study indicated that the combination of red and blue LED lights at $\mathrm{R}_{30} \mathrm{~B}_{70}$ is the best spectrum for effective in vitro tuberization of potatoes.
\end{abstract}

Key words: carbohydrates, light-emitting diodes; lipoxygenase; potato; proteins

\section{INTRODUCTION}

Potato (Solanum tuberosum L.) is a tuber crop grown worldwide for its essential participation in economy and nutrition. The potato is considered the third most important food crop after rice and wheat in terms of human consumption (Bagri et al. 2018). The potato is an annual, herbaceous, dicotyledonous, and vegetative propagated plant, which tubers are formed under short days and cool nights (Sarkar 2008). The vulnerability to different abiotic stresses as well as viral and fungal infections is a key challenge for potato cultivation that results in loss of quality and yield. Therefore, aseptic in vitro production of infection-free microtubers as potato seeds is preferred over other methods (Park et al. 2009; Chen et al. 2018).

The potato tuberization phenomenon is a complex developmental process that is controlled by several environmental and cellular factors. The tuberization starts with the growth of underground shoots - stolons, which terminal fragments develop into tubers. The induction of potato tubers mainly depends on environmental factors, including photoperiod (Jackson 1999), temperature (Xu et al. 1998), and age of the potato plant (Carrera et al. 1999). 
Tuberization is also known to be regulated by the availability of carbohydrates, in particular, sucrose, the transported form of sugar, which is required for the synthesis of starch, which ultimately depends on the photosynthesis (Raíces et al. 2001). The wavelength and duration of light irradiation have also been recognized as crucial environmental factors that affect the growth and development of plants under natural as well as in vitro conditions (Seabrook et al. 1995; Tadesse et al. 2001). Plants sense and absorb various light spectra through the photoreceptors and phytochrome sensory system, which is present in the photosynthetic organs. Multiple molecular forms of phytochromes have been recognized in plants, which are expressed at different levels in cells in response to various environmental and physiological cues (Kurilčik et al. 2008; Milinkovic et al. 2012). It has also been observed that the plant phytochromes absorb red light spectrum $(600-700 \mathrm{~nm})$, while the cryptochromes absorb blue light (400$500 \mathrm{~nm}$ ) (Halterman et al. 2016). The morphogenesis in potatoes and subsequent growth of microtubers were also reported to be influenced by the wavelength and duration of light. The high irradiance of light, short-day photoperiod, and a lower temperature have been recognized as the most significant environmental signals that impact the tuber formation in potatoes. The red and blue light spectra have been recognized as controlling factors for induction and growth of microtubers in potatoes (Cope et al. 2014; Huché-Thélier et al. 2016). Biochemical and molecular studies of potato tuberization revealed that the tuber induction starts with the perception of appropriate environmental signals in the aerial parts of the plant through phytochrome B and subsequent changes in the plant hormone, which then transmit the signal to the underground stolons to commence tuber formation (Smith 1994). Photoperiodic-controlled biosynthesis of the plant gibberellins (GAs) coordinates the stolon formation and tuber initiation; however, the GA endogenous level is regulated by the sucrose and its antagonistic hormone, the abscisic acid (ABA). Thus, the lightinduced signals alter the plant hormone levels that finally regulate the tuber induction in potatoes (Aksenova et al. 1989; Fixen et al. 2012).
Moreover, it was found that the activation of some genes of the tuberization pathway at the level of transcription is regulated by the protein dephosphorylation mechanism, which ultimately depends on the concentration of cytosolic $\mathrm{Ca}^{2+}$. Various extrinsic and intrinsic stimulus including the light irradiation regulates the cellular $\mathrm{Ca}^{2+}$ level, which ultimately alters the expression of the major calcium-mediated pathway genes including the calmodulin (StCaMI) and calcium-dependent protein kinases $(S t C D P K 1)$ in the tissues ready for the tuber formation (Jena et al. 1989; Raíces et al. 2001; 2003; Upadhyaya et al. 2016). Role of farred and blue light in the positive regulation of cytosolic $\mathrm{Ca}^{2+}$ concentration in higher plants and mosses has already been reported (Russell et al. 1998; Harada et al. 2003; Harada \& Shimazaki 2007). Moreover, the cellular induction of reactive oxygen species (ROS) was reported to induce the expression of the lipoxygenase (LOX) cascade in potato resulting in change of vital plant hormone including the GA and tuberonic acid (TA) leading to the onset of tuberization (Grant et al. 2000; Kolomiets et al. 2001; Nam et al. 2005). Thus, the tuberization in potatoes is a coordinated function of the various calcium-signaling pathways leading to change in the regulating proteins, and also lipoxygenase-derived metabolites result in potato tuberization (Sarkar 2008; Upadhyaya et al. 2013). Light quality also regulates carbohydrate metabolism and photosynthetic assimilation in plants (Kowallik 1982). The red-light irradiation has been reported to affect the synthesis of soluble sugar as well as starch in the leaves; however, the blue light spectra were found to induce the biosynthesis of soluble proteins in the plant (Li et al. 2017). Blue light has also been reported to stimulate the synthesis of amino acid content in Zea mays (Felker et al. 1995). Thus, the plant exposed to particular combinations of red and blue light spectra might exhibit increased starch and protein content with improved plant growth parameters. The artificial light illuminating with the light-emitting diodes (LEDs) of requisite wavelength of light has been used for better growth and development of various plant species (Schuerger et al. 1997). 
There are scanty reports on the optimal combinations of red (R) and blue (B) light spectra on potato growth and development under the in vitro condition. Thus, our study aimed to investigate the effect of LED light with red, blue spectra, and their various combinations on in vitro tuberization of potato and to find out the perfect combination of the LED light spectrum for industrial-level development of pathogen-free potato microtubers as seeds. The study also discussed the biochemical and molecular investigations on the stimuli of LED light spectrum on potato tuberization.

\section{MATERIALS AND METHODS}

\section{Plant material and culture conditions}

Solanum tuberosum 'Kufri Jyoti' is widely cultivated in India. For the experiment tubers were provided by the Central Potato Research Institute (CPRI, Shimla, India). The characteristics of cultivar include the early time to maturity, medium-size tubers, and upright plant type. The experiments were done at Potato Phenomics Laboratory established at Department of Biotechnology, Dr. Harisingh Gour Vishwavidyalaya (A Central University), Sagar, Madhya Pradesh, India $\left(23.8388^{\circ} \mathrm{N}, 78.7378^{\circ} \mathrm{E}\right)$. The potato tubers collected were washed in running water, dried, and sprouted under dark conditions at $37{ }^{\circ} \mathrm{C}$ with $80 \%$ relative humidity. The sprouted plantlets $(4-5 \mathrm{~cm}$ in height) were then transferred to the medium-size pots $(25 \mathrm{~cm})$ filled with coco-peat and sand $(3: 1$ ratio). The plants were maintained in the plant growth chambers (Matrix Eco India, size $1.5 \mathrm{~m} \times$ $1.2 \mathrm{~m} \times 2 \mathrm{~m}$, providing a total growth area of $4.2 \mathrm{~m}^{2}$ with $40-\mathrm{cm}$ high clearance) at $22 \pm 2{ }^{\circ} \mathrm{C}$ temperature $16 / 8 \mathrm{~h}$ photoperiod exposed to the fluorescent light and required humidity $(65 \pm 10 \%)$. The plants were watered with tap water as per requirements.

The stem taken from 4- to 6-week-old plants were cut into pieces $(1.5 \mathrm{~cm})$ containing nodal part, washed with detergent (Triton-X100), and disinfected with $0.1 \%$ sodium hypochlorite followed by $70 \%$ ethanol and then washed thrice with autoclaved water, and dried under the laminar flow.
Single nodal explants were aseptically inoculated into the Murashige and Skoog (1962) medium (MS) containing 3\% sucrose and $0.8 \%$ agar adjusted to $\mathrm{pH}$ 5.8. The cultures were incubated at $22 \pm 2{ }^{\circ} \mathrm{C}$ with $60 \%$ relative humidity in the plant growth chamber fitted with different LED lights. Each treatment contained 60 nodal explants, and a total of 180 explants were taken upon repeating the experiment thrice.

\section{The light source and culture conditions}

The LED light source was procured from the supplier (Sagar, Madhya Pradesh, India) with the corresponding red $(650 \mathrm{~nm})$ and blue $(460 \mathrm{~nm})$ wavelength. The LED source comprised stripes $(5 \times 100 \mathrm{~cm})$ containing 40 LEDs, which created a light-emitting set with $100 \mu \mathrm{mol} \cdot \mathrm{m}^{-2} \cdot \mathrm{s}^{-1}$ total photosynthetic photon flux density (PPFD). The nodal tissues were maintained under the exposure of red (R) and blue (B) LED such as $100 \% \mathrm{R}$ $\left(\mathrm{R}_{100}\right), 100 \% \mathrm{~B}\left(\mathrm{~B}_{100}\right)$, and their combinations of $\mathrm{RB}$ such as $30 \% \mathrm{R}$ and $70 \% \mathrm{~B}\left(\mathrm{R}_{30} \mathrm{~B}_{70}\right), 50 \% \mathrm{R}$ and $50 \% \mathrm{~B}\left(\mathrm{R}_{50} \mathrm{~B}_{50}\right)$, and $70 \% \mathrm{R}$ and $30 \% \mathrm{~B}$ $\left(\mathrm{R}_{70} \mathrm{~B}_{30}\right)$ LED spectra. The nodal tissues maintained under $\mathrm{W}_{100}$ LED without supplementation of red and blue lights were used as a control, while the nodal tissues maintained under continuous dark were used as a positive control. The photoperiod, photosynthetic photon flux density (PPFD), day/night temperature, and relative humidity in the plant growth chamber were set as $16 / 8 \mathrm{~h}$ (day/night), $210 \mu \mathrm{mol} \cdot \mathrm{m}^{-2} \cdot \mathrm{s}^{-1}, 22 \pm 2{ }^{\circ} \mathrm{C}$, $65 \pm 10 \%$, respectively.

\section{Sample collection and analysis of microtubers}

The percentage of in vitro tuberization was calculated according to the number of stolons (arising on the nodal cuttings) converting into tubers divided by the total number of the inoculated singlenode cuttings. The stolons and further developed tuber samples were collected individually upon each LED light treatment. Observations on the tuber induction period, number of stolons converting to initial tubers, the total number of tubers, tuber weight, and overall yield were taken upon 30 days of tuber induction. 


\section{Biochemical analysis of microtubers Estimation of total carbohydrates and soluble proteins}

The soluble sugar content in tubers was extracted as described (Ciha \& Brun 1978) and quantified using the phenol-sulfuric acid method (Dubois et al. 1956). Concentrated sulfuric acid hydrolyzes the glycosidic linkages to neutral sugars, which then partially dehydrated via elimination of three molecules of water to form furfural or furfural derivatives. The colored compounds developed by the condensation of furfural or furfural derivatives with phenol were estimated using the spectrophotometer (Shimadzu 1800, Japan) at $490 \mathrm{~nm}$. Various concentrations of D-glucose $\left(10-100 \mu \mathrm{g} \cdot \mathrm{ml}^{-1}\right)$ were used as standards for the estimation of total carbohydrates. The tuber starch was hydrolyzed into simple sugars using perchloric acid, and the quantity of simple sugars was estimated by the anthrone method (Sadasivam \& Manickam 1992). The D-glucose solution $\left(50-500 \mu \mathrm{g} \cdot \mathrm{ml}^{-1}\right)$ was used as a standard for the estimation of starch.

Extraction of the soluble proteins was done using the phosphate buffer following the standard protocol (Sambrook et al. 1989), and quantification of the protein was done using the Bradford reagent (Bradford 1976). Solution of bovine serum albumin $\left(1-10 \mu \mathrm{g} \cdot \mathrm{ml}^{-1}\right)$ was used as a standard for the estimation of total proteins.

\section{Molecular analysis of microtubers}

Expression analysis of tuberization signaling pathway genes

The calcium-dependent protein kinases (StCDPK), calmodulin proteins (StCaM1), and the resulting metabolites of the lipoxygenase (StLOX) pathway have been reported as the major signaling pathway genes regulating the potato tuberization. Total RNA was extracted from tuberizing tissues by using TRIzol reagent kit (Invitrogen, USA) following the manufacturer's instructions.

The SuperScript ${ }^{\mathrm{TM}}$ First-Strand cDNA synthesis kit (Invitrogen, USA) was used taking 1.0 $\mu \mathrm{g}$ RNA. A standard protocol was followed for the cDNA synthesis using Oligo-dT primers. The mixture was incubated at $42{ }^{\circ} \mathrm{C}$ for $50 \mathrm{~min}$ to complete the reverse transcription reaction (Sambrook et al. 1989).
The cDNA was used as a template for the quantitative gene expression analysis. Real-time quantitative amplification (q-PCR) of the major tuberization pathway genes, such as $C a M 1, S t C D P K$, and $L O X$, was carried out in a real-time PCR system (Applied Biosystems, USA) using the gene-specific primers. The RT-PCR reaction was performed using the SYBR-green real-time PCR kit (Invitrogen, USA). The actin (NCBI accession No. XM_015308091.1) gene-specific primers were used as an internal gene amplification control where the proportional threshold $(\mathrm{Ct})$ values were normalized to the actin gene to achieve the comparative expression. Different primer sequences used for the qPCR analysis are shown in Table 1.

\section{Lipoxygenase enzyme assay}

The in vitro grown stolons and tuber tissues developed from the single nodal explants upon the treatment with various LED lights were collected simultaneously depending on their stage of formation. The proteins were extracted following the standard protocol (Sambrook et al. 1989). The LOX activity was quantified using the extracted proteins following the procedure as reported (Gökmen et al. 2002). A standard substrate solution was prepared via mixing $2.0 \mathrm{ml}$ of potassium phosphate buffer (0.1 M; pH 6.0), $2.0 \mu \mathrm{l}$ of Tween-20, and $2.0 \mu \mathrm{l}$ of pure linoleic acid (Sigma, USA). The gentle stream of air was passed through the solution for aeration, and the reaction was initiated by adding $100 \mu \mathrm{l}$ of crude enzyme extract to the solution. The blank consisted of only substrate solution $(2.0 \mathrm{ml})$ added with distilled water $(100 \mu \mathrm{l})$. The synthesis of hydroperoxides due to the presence of a conjugated hydroperoxydiene moiety was monitored using the spectrophotometer (Shimadzu 1800, Japan) at $234 \mathrm{~nm}$. One unit of LOX activity was defined as an increase in absorbance at min per $\mathrm{mg}$ of protein under assay conditions.

\section{Statistical analysis}

The data were reported as the mean of three replicates ( \pm standard error, SE). Data were analyzed by ANOVA and Tukey HSD test with the statistical package SPSS 15.0 unless otherwise stated. 


\section{RESULTS}

\section{Influence of various LED light spectra on the in vitro tuberization}

Exposure of $\mathrm{R}$ and $\mathrm{B}$ LED light spectra and their various combinations altered the in vitro tuberization process on the nodal tissues grown on the MS media (Fig. 1). An early stolons formation was observed on the nodal explants maintained under $\mathrm{R}_{100}$ (7-8 days) and $\mathrm{R}_{30} \mathrm{~B}_{70}$ (8-9 days) light spectra compared with other light treatments and the controls.
Observations further revealed that the stolons developed under the exposure of $\mathrm{R}_{30} \mathrm{~B}_{70}$ combination of LED light showed early tuber formation (within 12-14 days) and enhanced number of stolons converting into tubers $(143.67 \pm 5.37)$, with improved tuber size $(4.10 \pm 0.45 \mathrm{~mm})$, tuber weight, and tuber yield $(83.48 \pm 3.50 \mathrm{~g})$ in comparison with those under the exposure of other light spectra (Table 2). Interestingly, delayed tuber induction was also observed with the nodal tissues maintained without light and under $\mathrm{W}_{100}$.

Table 1. List of primers used in the RT-PCR analysis

\begin{tabular}{llll}
\hline Gene & Accession No. & \multicolumn{1}{c}{ Forward primer 5'-3' } & \multicolumn{1}{c}{ Reverse primer 5'-3' } \\
\hline LOX & X79107.1 & AGAGGAGATGGAACTGGAAAG & CTCGGTACATAGATGTCTAAGC \\
\hline StCaM1 & J04559.1 & GCTGATCAGAATGGAACCATTG & CAATATCTGCCTCTCGGATCAT \\
\hline StCDPK & AF115406.3 & CTGGTCCGAAAGATGCTCAAT & CTGCTGAGAGATTCTCAGCA \\
\hline ACTIN & X55749.1 & GAATGGAAGCAGCTGGAATC & CTGGTGGTGCAACAACCTTA \\
\hline
\end{tabular}

Table 2. Effect of various spectra of LED lights on in vitro tuberization of potato 'Kufri Jyoti'

\begin{tabular}{lccccccc}
\hline $\begin{array}{c}\text { Light } \\
\text { treat- } \\
\text { ments }\end{array}$ & $\begin{array}{c}\text { Number } \\
\text { of explants } \\
\text { showing stolons } \\
\text { formation }\end{array}$ & $\begin{array}{c}\text { Days } \\
\text { to stolon in- } \\
\text { duction/for- } \\
\text { mation }\end{array}$ & $\begin{array}{c}\text { Number } \\
\text { of stolons } \\
\text { converting } \\
\text { to the tubers }\end{array}$ & $\begin{array}{c}\text { Days } \\
\text { to tuber } \\
\text { induction }\end{array}$ & $\begin{array}{c}\text { Tuber size } \\
(\mathrm{mm})\end{array}$ & $\begin{array}{c}\text { Tuber weight } \\
(\mathrm{g})\end{array}$ & $\begin{array}{c}\text { Total tuber yield } \\
(\mathrm{g})\end{array}$ \\
\hline $\mathrm{R}_{100}$ & $146.55 \pm 3.99 \mathrm{~b}$ & $7-8$ & $91.55 \pm 3.34 \mathrm{e}$ & $18-21$ & $1.82 \pm 0.31 \mathrm{e}$ & $0.32 \pm 0.06 \mathrm{e}$ & $49.6 \pm 1.54 \mathrm{~d}$ \\
\hline $\mathrm{B}_{100}$ & $121.2 \pm 3.18 \mathrm{~d}$ & $11-13$ & $110.2 \pm 3.15 \mathrm{~b}$ & $17-18$ & $5.30 \pm 0.31 \mathrm{a}$ & $0.58 \pm 0.15 \mathrm{a}$ & $70.52 \pm 2.69 \mathrm{~b}$ \\
\hline $\mathrm{R}_{30}: \mathrm{B}_{70}$ & $158.5 \pm 4.38 \mathrm{a}$ & $8-9$ & $143.67 \pm 5.37 \mathrm{a}$ & $12-14$ & $4.10 \pm 0.45 \mathrm{~b}$ & $0.51 \pm 0.06 \mathrm{~b}$ & $83.48 \pm 3.50 \mathrm{a}$ \\
\hline $\mathrm{R}_{50}: \mathrm{B}_{50}$ & $118.2 \pm 3.15 \mathrm{e}$ & $11-12$ & $102.50 \pm 2.33 \mathrm{c}$ & $18-20$ & $3.11 \pm 0.21 \mathrm{~cd}$ & $0.40 \pm 0.12 \mathrm{~d}$ & $46.46 \pm 2.47 \mathrm{~d}$ \\
\hline $\mathrm{R}_{70}: \mathrm{B}_{30}$ & $133.22 \pm 3.02 \mathrm{c}$ & $10-11$ & $97.21 \pm 3.15 \mathrm{~d}$ & $18-20$ & $3.4 \pm 0.36 \mathrm{c}$ & $0.44 \pm 0.07 \mathrm{c}$ & $57.17 \pm 1.23 \mathrm{c}$ \\
\hline $\mathrm{W}_{100}$ & $118.55 \pm 4.18 \mathrm{e}$ & $13-15$ & $92.20 \pm 2.15 \mathrm{e}$ & $24-26$ & $3.64 \pm 0.21 \mathrm{c}$ & $0.40 \pm 0.17 \mathrm{~d}$ & $46.79 \pm 3.87 \mathrm{~d}$ \\
\hline Dark & $108.41 \pm 5.34 \mathrm{f}$ & $10-11$ & $98.65 \pm 2.15 \mathrm{~d}$ & $19-21$ & $2.87 \pm 0.28 \mathrm{~d}$ & $0.34 \pm 0.20 \mathrm{e}$ & $42.79 \pm 1.29 \mathrm{e}$ \\
\hline
\end{tabular}

Values are mean \pm standard errors of three repeated experiments $(n=3)$. No. of explants inoculated per treatment was 60 with a total of 180 explants per treatment. Values represent mean \pm SE, and different letters indicate significant differences $(p \leq 0.05)$ in the values according to Tukey HSD test

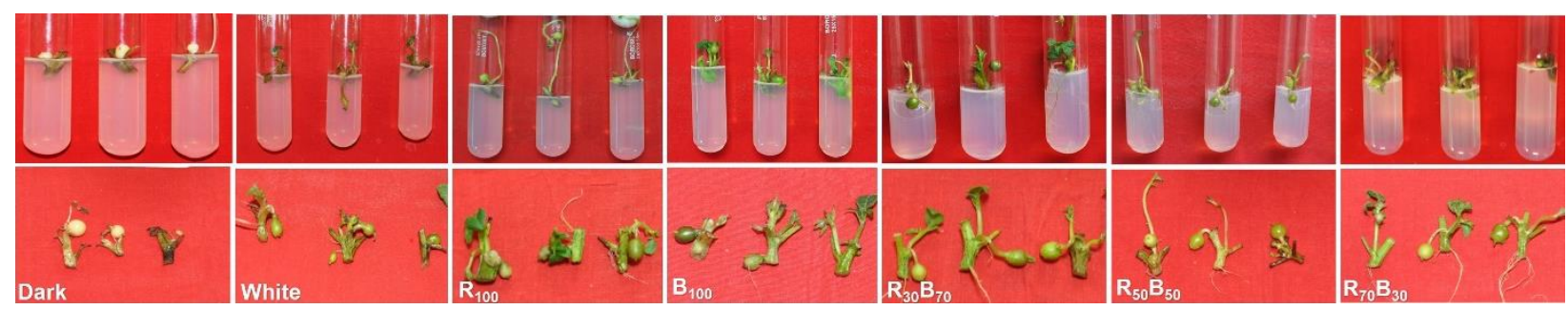

Figure 1. Influence of various LED light spectra on in vitro tuberization in potato 'Kufri Jyoti'. Nodal explants were used for the tuberization studies. Early tuber formation was observed through the subapical swelling of the nodal region maintained on MS basal medium under $\mathrm{R}_{30} \mathrm{~B}_{70}$ combination LED light spectra. Abbreviations: $\mathrm{R}_{100}-100 \%$ red; $\mathrm{B}_{100}-100 \%$ blue; $\mathrm{R}_{30} \mathrm{~B}_{70}-30 \%$ red and $70 \%$ blue; $\mathrm{R}_{50} \mathrm{~B}_{50}-50 \%$ red and $50 \%$ blue; $\mathrm{R}_{70} \mathrm{~B}_{30}-70 \%$ red and $30 \%$ blue 
Quantification of carbohydrates and protein content in tissues grown under LED light

A slight increase in the total soluble sugar content was observed with the microtubers developed under the exposure of the $\mathrm{R}_{30} \mathrm{~B}_{70}\left(8.1 \pm 0.42 \mathrm{mg} \cdot \mathrm{g}^{-1}\right.$ of tuber FW) and $R_{100}\left(7.9 \pm 0.71 \mathrm{mg} \cdot \mathrm{g}^{-1}\right.$ of tuber FW) compared with those developed under $\mathrm{W}_{100}$ and other light combination (Fig. 2A). The highest starch and protein contents in the microtuber tissues were found under the $\mathrm{B}_{100}$ and the $\mathrm{R}_{30} \mathrm{~B}_{70}$. The $\mathrm{R}_{30} \mathrm{~B}_{70}$ combination of LED light spectra induced maximum content of starch $\left(174.1 \pm 5.76 \mathrm{mg} \cdot \mathrm{g}^{-1}\right.$ tuber FW $)$ and the protein $\left(24.2 \pm 1.65 \mathrm{mg} \cdot \mathrm{g}^{-1}\right.$ tubers FW). The lowest content of starch was quantified in the microtubers grown under the $\mathrm{W}_{100}$ light (Fig. 2B-C).

Expression analysis of tuberization pathway genes The qPCR analysis of major tuberization-specific genes, such as calmodulin (StCaMI), calcium-dependent protein kinase $(S t C D P K)$, and the lipoxygenase $(L O X)$, indicated a significantly enhanced expression in the stolon tissues developed under the exposure of $\mathrm{R}_{100} \mathrm{LED}$ (2.65-, 2.84-, and 3.21-folds, respectively) followed by the $\mathrm{R}_{30} \mathrm{~B}_{70}$ combination of LED light (2.39-, 2.56-, and 2.95-folds, respectively) as compared with the control (Fig. 3A). The expressions of StCaMl, $S t C D P K$, and $L O X$ in the initial tuber tissues developed under the exposure of $\mathrm{R}_{30} \mathrm{~B}_{70}$ and $\mathrm{B}_{100} \mathrm{LED}$ light were significantly enhanced in comparison with the other light combinations and the control $\mathrm{W}_{100}$ light as well as the dark conditions. Exposure to $\mathrm{R}_{30} \mathrm{~B}_{70}$ LED light enhanced the expression of the StCaM1, StCDPK, and LOX genes by 1.93-, 2.01-, and 2.20-folds, respectively, in comparison with the control light conditions as shown in Figure 3B. In addition, an enhanced expression of these genes was also observed in the developed tuber tissues grown under $\mathrm{R}_{30} \mathrm{~B}_{70} \mathrm{LED}$ light combination in comparison with those grown under dark and $\mathrm{W}_{100}$. A noteworthy reduction in the expression of all the genes was observed in the developed tubers grown under all kinds of light spectra (Fig. 3C).

Estimation of lipoxygenase enzyme activity in tuberizing tissues

Spectrophotometric analysis depicted an enhanced LOX enzyme activity in stolons and initial and developed tuber tissues grown under the exposure of $\mathrm{B}_{100}$ and $\mathrm{R}_{30} \mathrm{~B}_{70}$ light combinations. The $\mathrm{R}_{30} \mathrm{~B}_{70} \mathrm{LED}$ spectrum induced the LOX activity by 2.20 -fold in stolon (Fig. 4A), 2.06-fold in initial tubers (Fig. 4B), and 1.74-fold in developed tubers (Fig. 4C), respectively, in comparison with the $\mathrm{W}_{100}$ LED light. The LOX activity was also enhanced in the stolons, initial tubers, and developed tuber tissues under the $\mathrm{B}_{100}$ LED light as compared with the control light condition. The increase in the LOX enzyme activity in the stolons and tuber tissues also coincides with the enhanced $L O X$ gene expression as was evident in the qPCR analysis as represented in Figure 3.
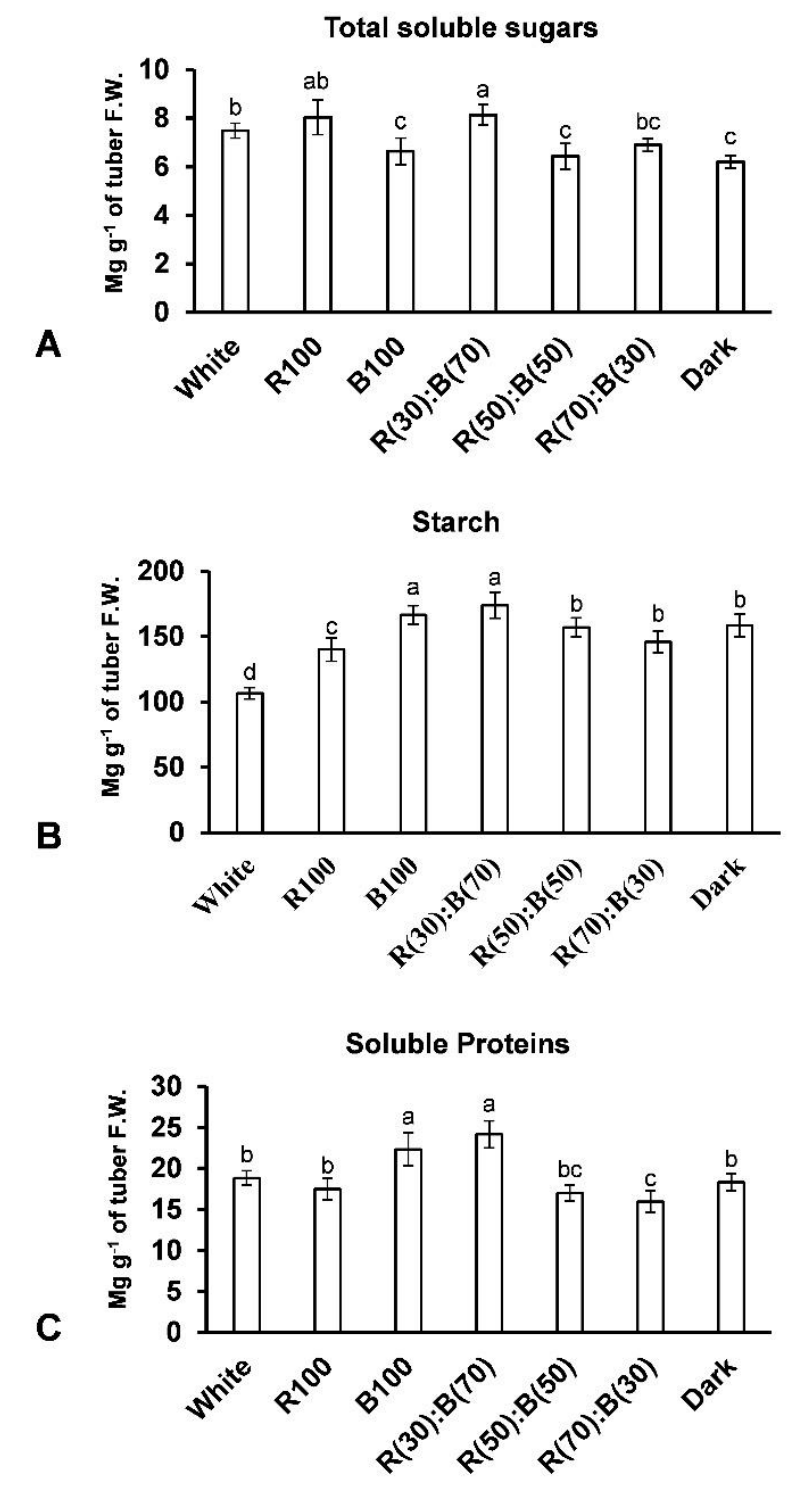

Figure 2. Analysis of total soluble sugar, starch and the protein content in the microtuber developed under various LED spectra of light. A - total soluble sugar, B - starch content, and $\mathrm{C}$ - proteins in tuber tissues of potato. Values are means \pm SE of three replicate experiments $(n=3)$. Bars marked with letters indicate significant differences according to the Tukey HSD test $(\mathrm{p}<0.05)$. Abbreviations: See Figure 1 

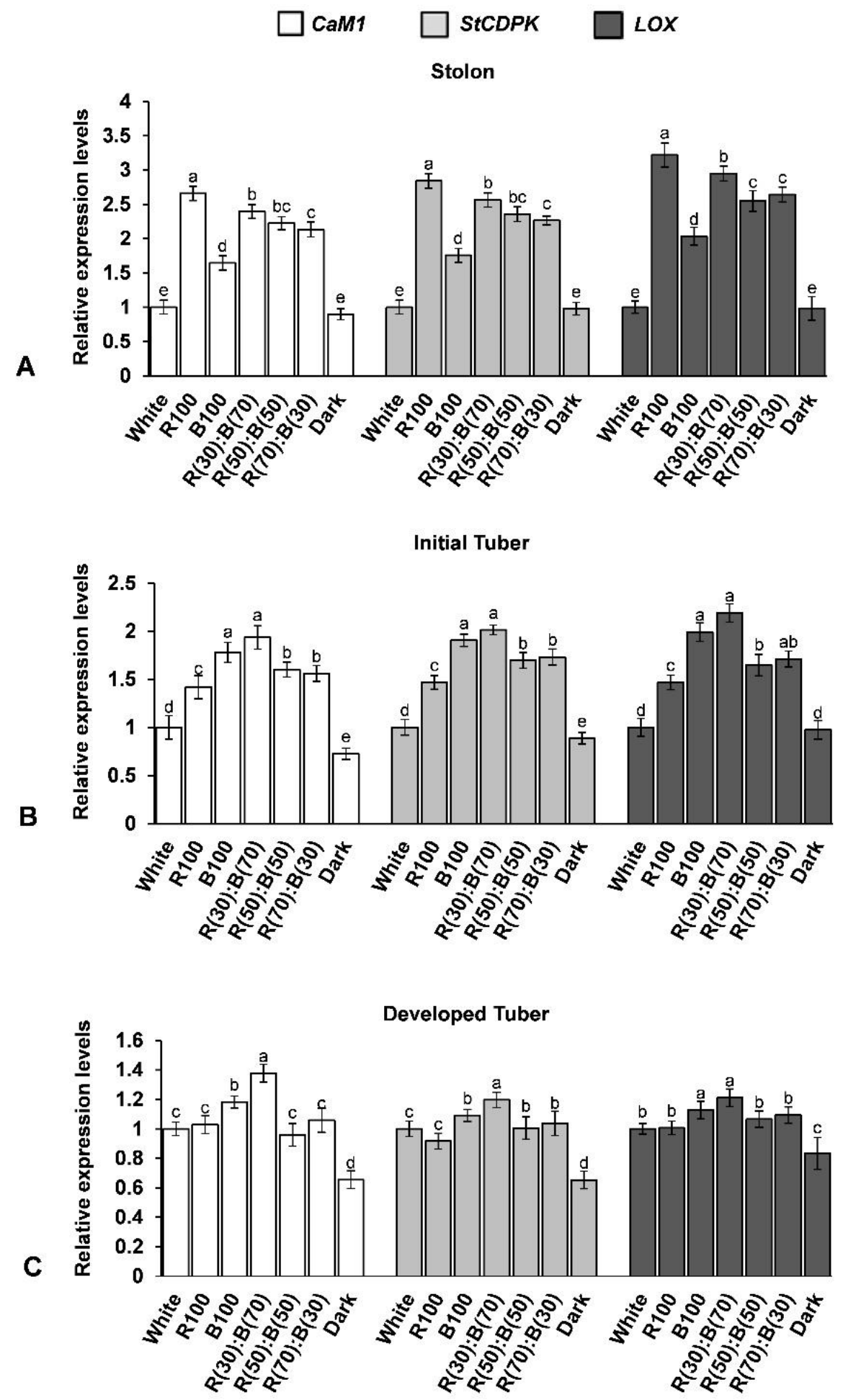

Figure 3. Expression analysis of CaM1, StCDPK and $L O X$ genes in stolon, initial tuber, and developed tuber tissues of potato. A - expression analysis in the stolon tissues, B - expression analysis in initial tuber, and $\mathrm{C}$ - expression analysis in the developed tuber. Data analyzed by the comparative delta $\mathrm{Ct}$ method. Bars marked with letters indicate significant differences according to the Tukey HSD test ( $\mathrm{p}<0.05$ ). Abbreviations: $\mathrm{R}_{100}-100 \%$ red; $\mathrm{B}_{100}-100 \%$ blue; $\mathrm{R}_{30} \mathrm{~B}_{70}-30 \%$ red and $70 \%$ blue; $\mathrm{R}_{50} \mathrm{~B}_{50}$ $-50 \%$ red and $50 \%$ blue; $\mathrm{R}_{70} \mathrm{~B}_{30}-70 \%$ red and $30 \%$ blue; CaM1 - calmodulin-1; StCDPK - calciumdependent protein kinase; LOX - lipoxygenase 

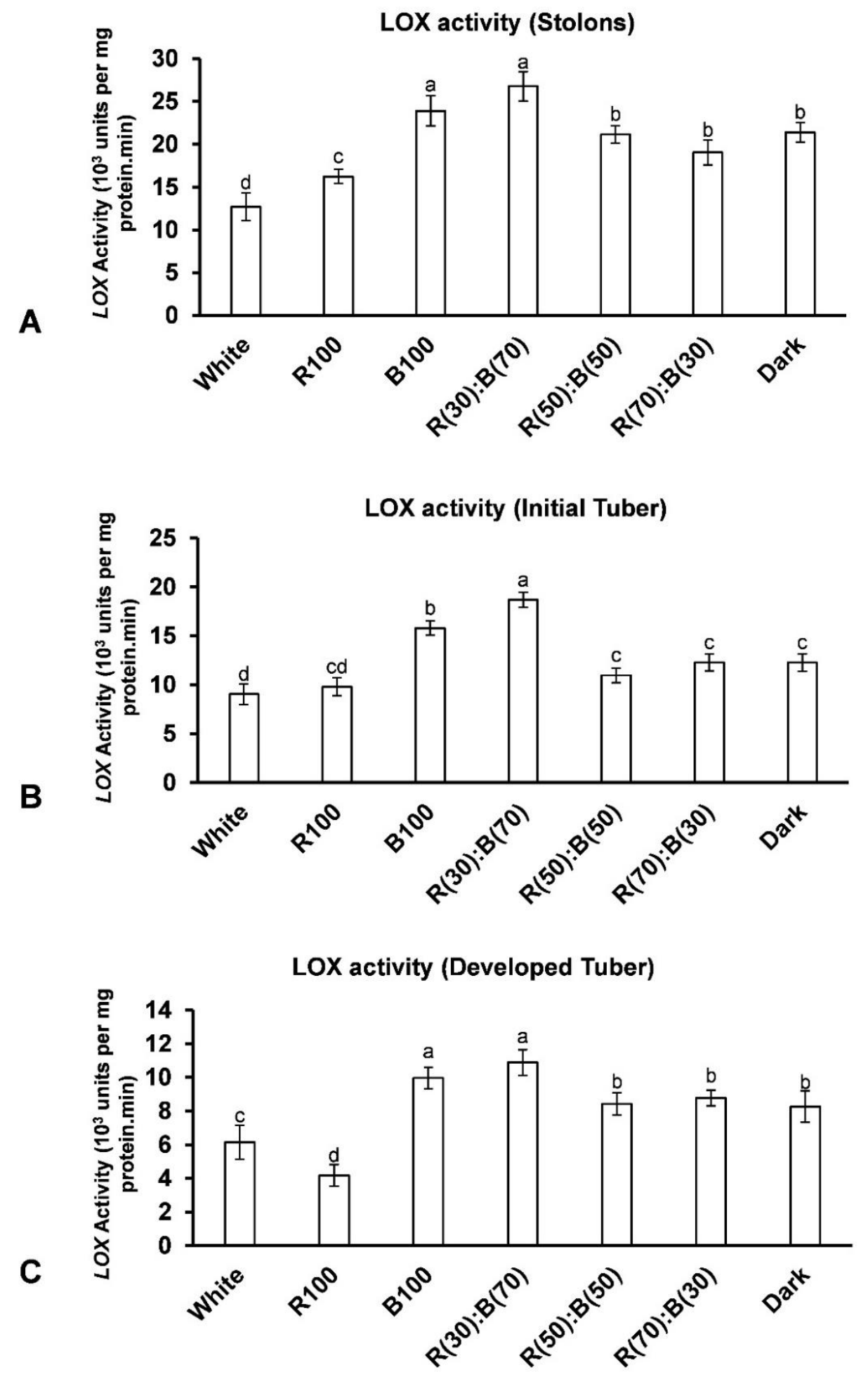

Figure 4. Lipoxygenase enzyme activity in various tuberizing tissues of potato during in vitro tuberization under various LED light spectra. A - LOX enzyme activity in stolons; B - LOX enzyme activity in initial tubers; C - LOX enzyme activity in developed tubers. Values are mean $\pm \mathrm{SE}$ of three replicate experiments $(\mathrm{n}=3)$. Bars marked with letters indicate significant differences according to the Tukey HSD test $(\mathrm{p}<0.05)$. Abbreviations: $\mathrm{R}_{100}-100 \%$ red; $\mathrm{B}_{100}-100 \%$ blue; $\mathrm{R}_{30} \mathrm{~B}_{70}-30 \%$ red and $70 \%$ blue; $\mathrm{R}_{50} \mathrm{~B}_{50}-50 \%$ red and $50 \%$ blue; $\mathrm{R}_{70} \mathrm{~B}_{30}-70 \%$ red and $30 \%$ blue; $\mathrm{LOX}$ - lipoxygenase 


\section{DISCUSSION}

\section{RB combination of LED light spectra enhanced the in vitro tuberization}

Various spectra of light impact photosynthesis and morphogenesis and hence alter plant growth and developmental process (Seabrook 2005; Li et al. 2018). The results exhibited that the degree of in vitro tuberization on the nodal explants varied with exposure to different LED lights; therefore, it was tempting to find out the pathway reliant upon the light involved in tuberization. The one important reason might be the difference in the photosynthetic capacity, hormone content, and efficient translocation of carbohydrates from the source (MS media in the case) under different spectra of LED light which resulted in varied tuberization. The light-mediated regulation of the endogenous plant hormones, including GA, abscisic acid (ABA), and indole acetic acid (IAA), has already been reported (Aksenova et al. 1989; Fixen et al. 2012; Matsuo et al. 2019). The GA has been recognized as an important plant hormone regulating the photoperiodic-mediated tuberization in the potato and reported to induce stolon formation via the longitudinal cell expansion by the transverse orientation of microtubules and microfibrils to the cell axis (Aksenova et al. 1989). Thus, the plant hormone GA plays an essential role in stolon formation and elongation during tuber formation; however, its higher concentration prevents the conversion of stolons to tubers (Fixen et al. 2012). A recent report also exhibited an increase in bioactive GA content in the plant grown under the R LED compared with those grown under other light conditions (Matsuo et al. 2019). However, the addition of the B LED to $\mathrm{R}$ light increased the transcript level of the GA inactivation gene, thus balancing endogenous GA contents in the plants. The GA level decreases when stolon tips started to swell to form the initial tuber (Sarkar 2008). In this study, an early stolon induction was observed in the case of the nodal explants growing under the $\mathrm{R}_{100} \mathrm{LED}$ light; however, a lesser number of initial tubers with lower mass per tuber were also observed (Table 2).
This might be due to continuous biosynthesis of the endogenous GA content under the $\mathrm{R}_{100}$ monochromatic light, which induced the stolons formation, but the efficiency of conversion of stolons to the tuber was redundant. In addition, it was observed that the nodal explants growing under the $\mathrm{B}_{100}$ LED light showed delayed stolon initiation and tuber formation but increased the number of tubers with the greater mass per tuber. This might be due to reduction in the GA content essential for the conversion of the stolons to tubers. However, insufficient biosynthesis of bioactive GA content under $\mathrm{B}_{100}$ LED light might have delayed the stolon initiation. The combined spectra of $R_{30} B_{70}$ LED efficiently provided the required wavelength of light, resulting in biosynthesis of balanced hormone GA and IBA for early stolons formation, efficient conversion of the stolons into the tuber, and translocation of the carbohydrates (from either media or the nodal explants) for early tuberization with enhanced tuber mass and yield.

Increase carbohydrates and soluble protein content in microtubers under RB LED light

The light quality has been recognized as an essential factor regulating the protein and carbohydrate metabolism in plants and the transportation, as well as accumulation of soluble carbohydrates such as starch which ultimately determine the growth of tuber tissues of potato (Malone et al. 2006; Asghari-Zakaria et al. 2009; Kang et al. 2013). The blue light has been reported to induce sugar and starch contents in potato tuberizing under the in vitro conditions on the growth media $(\mathrm{Li}$ et al. 2020). A similar result was also observed in this study. An increase in starch content in microtubers grown under $\mathrm{B}_{100}$ LED spectra represented the accumulation of starch content in the tuber tissues, which was also associated with the increase in the tuber size and mass. Similar results of enhanced biosynthesis of the starch and protein in the tissues under the $\mathrm{B}$ dominant light conditions validated our study (Chen et al. 2020; Li et al. 2017). However, the soluble sugar content in microtubers developed under $\mathrm{R}_{100}$ LED light remained higher which indicated a reduction in transportation and accumulation of sucrose as starch in the tissues. 
Quantification of the starch and soluble protein content enhanced in the tuber tissues developed under the exposure of $\mathrm{R}_{30} \mathrm{~B}_{70}$ combination of LED light indicated better translocation of the available carbohydrates from the growth medium leading to storage of starch in the tuber.

\section{Induction of tuberization pathway genes}

The change in the concentration of cytosolic $\mathrm{Ca}^{2+}$ is one of the primary events in the transduction of different signals leading to variation in metabolic processes. The concentration of free cytosolic $\mathrm{Ca}^{2+}$ in plant cells elevates via various extrinsic and intrinsic stimuli. The calcium-binding proteins are present in the cell initiate downstream signaling events leading to alteration in gene expression resulting in variation in the morphological and physiological parameters (Tuteja \& Mahajan 2007; Khan et al. 2014). In case of potato tuberization, the change in cytosolic $\mathrm{Ca}^{2+}$ triggers a cascade of phosphorylation of tuber-inducing proteins including the calciumbinding modulator proteins (calmodulin, StCaMI) and calcium-dependent protein kinases (StCDPK1) (Jena et al. 1989; Raíces et al. 2001; Upadhyaya et al. 2016). These proteins have been recognized as a key mediator in sucrose-signaling pathways during tuber induction and development (MacIntosh et al. 1996; Raíces et al. 2003). The blue and red-light irradiations have been reported to enhance the cytosolic $\mathrm{Ca}^{2+}$ through the $\mathrm{Ca}^{2+}$ channels via the action of phototropin 1 and two proteins (Babourina et al. 2002; Harada et al. 2003; Stoelzle et al. 2003). In this study, an early tuber induction, increase in tuber number, and yield under the $\mathrm{R}_{30} \mathrm{~B}_{70}$ could also be attributed to enhanced expression of the calcium-dependent $S t C a M 1$ and $S t C D P K$ gene as evident in the qPCR expression analysis (Fig. 3). Therefore, change in concentrations of cytosolic $\mathrm{Ca}^{2+}$ due to the combined RB LED spectrum could be a major factor in enhanced expression of the calcium-signaling pathway genes leading to early tuber induction and tuber yield as evident in this study.

Variation in cytosolic $\mathrm{Ca}^{2+}$ also resulted in the $S t C D P K$-mediated activation of the NADPH oxidase and cellular oxidative burst, which ultimately induced an intracellular signaling pathway resulting in the generation of reactive oxygen species (ROS) that damage membrane lipids and proteins (Grant et al. 2000; Kobayashi et al. 2006). In addition to ROS, the enhanced LOX enzyme which activity was highly correlated with the cellular redox state also catalyzed the peroxidation of damaged membrane lipid components, particularly unsaturated fatty acids, which ultimately participated in the biosynthesis of the tuber-inducing essential plant hormones (Koda 1997; Maccarrone et al. 2000). The enhanced expression of the $L O X$ gene was also corroborated with induced tuber formation in potatoes as reported earlier (Nam et al. 2005). An enhanced expression of the LOX gene in the stolons and the developing tubers growing under the $\mathrm{R}_{30} \mathrm{~B}_{70}$ light spectrum might be due to the cytosolic change in the $\mathrm{Ca}^{2+}$ ions leading to enhanced ROS-mediated LOX cascade products inducing the in vitro tuberization. Products of the LOX cascade, such as jasmonic acid (JA) and tuberonic acid (TA), have been reported to play multiple roles as growth regulators, as well as signal molecules to initiate potato tuberization by antagonizing the effects of GA (Pinsky et al. 1971; Jackson \& Willmitzer 1994; Smith 1994). Moreover, the LOX enzyme activity strikes exclusively at the tip of stolons, developing tubers, which ultimately reduces at the maturing stage of the tuber formation (Kolomiets et al. 2001; Pelacho \& Mingo-Castel 1991). An enhanced LOX enzyme activity and gene expression in the stolons tissues and initial tubers were also observed in this study (Fig. 4A-B). Therefore, the $\mathrm{R}_{30} \mathrm{~B}_{70}$ combination of LED spectrum control the expression of the LOX genes in the tissues, resulting in an efficient in vitro tuberization even without the addition of external enzymes or sucrose in the growth medium. The report on LOX cascade-regulated tuber formation via direct interaction with light and low temperature suggested an important downstream signal molecule in photoperiod-controlled signaling pathways (Nam et al. 2005; 2008). Taken together, an association of change in the LOX activity profile and tuber formation under the in vitro condition exposed to the LED light irradiation could not be ignored. A line diagram describing the possible pathways involved in lightmediated induction of potato tuberization is presented in Figure 5. 


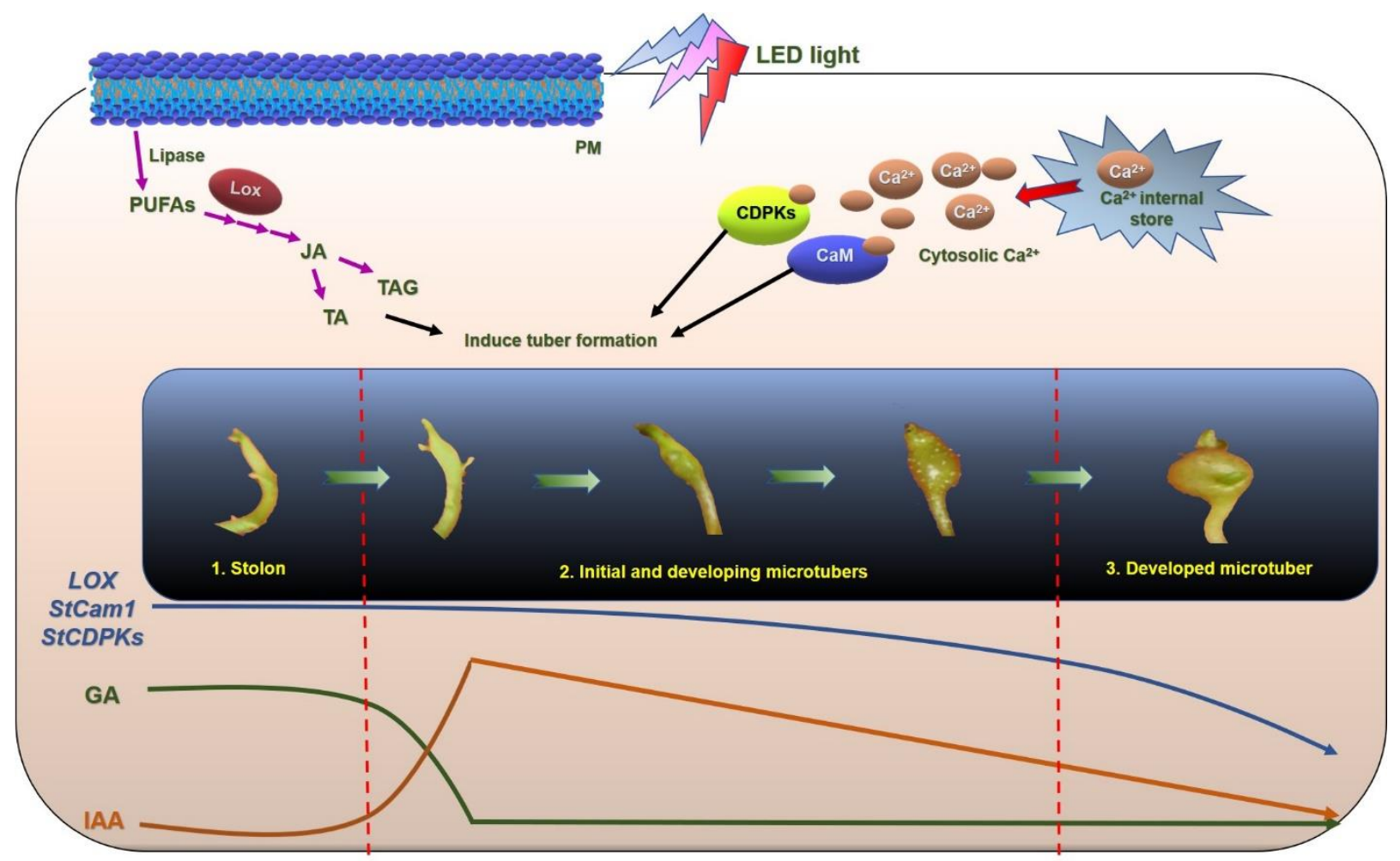

Figure 5. Line diagram describing possible mechanisms related to light-mediated induction of potato tuberization. LED light and its various combinations may involve alternation of hormonal and cytosolic $\mathrm{Ca}^{2+}$ ions, ultimately leading to an enhanced calcium-signaling pathway and LOX activity to increase tuberization on single nodal potato segments growing in a non-tuber inducing medium. Green and orange arrows show respectively GA and IAA levels at different stages of tuberization; the blue arrow shows the expression pattern of LOX, CaM, and StCDPK. Abbreviations: GA - gibberellic acid; IAA - indole 3 acetic acid; LOX - lipoxygenase; CaM - calmodulin; StCDPKs - calcium-dependent protein kinases; PUFAs - polyunsaturated fatty acids; JA - jasmonic acid; TA - tuberonic acid; TAG - tuberonic acid glucoside; PM - plasma membrane; LED - light-emitting diode

\section{CONCLUSIONS}

Thus, our study aimed to investigate the effect of LED light with red (R), blue (B) spectra, and their various combinations on in vitro tuberization of potato and to find out the perfect combination of the LED light spectrum for the production of pathogen-free potato microtubers as seeds on an industrial scale. The results showed that the combination of $30 \%$ red $+70 \%$ blue LED light shortens the tuber induction period and significantly increased tuber number and tuber yield compared with these parameters obtained in the tissues exposed to the complete dark or the white light. This induction of the in vitro tuberization was correlated with the increased synthesis of starch, soluble carbohydrates, and protein as well as an enhanced expression of the tuber induction pathway genes, including the lipoxygenase (StLOXI), calmodulin (CaMI), and calcium-dependent protein kinase (StCDPK).
The current study indicated that the above combination of red and blue LED lights proved to be the best light spectra for enhanced in vitro tuberization of potato.

\section{Acknowledgments}

The authors thank Dr. Harisingh Gour Central University, Sagar, India, for providing the departmental financial support to conduct the experiments. R.K.P. acknowledges the U.G.C. research fellowship from Dr. Harisingh Gour Central University, Sagar, Madhya Pradesh, India. A.P. acknowledges the fellowship as a junior research fellow from the DST-SERB project (SERB/000098/2017/426).

\section{Authors' contribution}

C.P.U. and D.C.U. have designed and supervised the research work and written the manuscript. R.K.P. and A.P. contributed to lab experiments, data collection, and analysis. C.P.U. and A.M. helped in data analysis, manuscript writing and editing.

\section{Compliance with ethical standards}

The authors declare no conflict of interest. 


\section{REFERENCES}

Aksenova N.P., Konstantinova T.N., Chailakhyan M.K. 1989. Morphogenetic effect of blue and red light in the illumination of underground and above-ground potato organs in in vitro cultivation. Doklady Akademii Nauk SSSR 305: 508-512. [in Russian]

Asghari-Zakaria R., Maleki-Zanjani B., Sedghi E. 2009. Effect of in vitro chitosan application on growth and minituber yield of Solanum tuberosum L. Plant, Soil and Environment 55(6): 252-256. DOI: 10.17221/1018-pse.

Babourina O., Newman I., Shabala S. 2002. Blue lightinduced kinetics of $\mathrm{H}^{+}$and $\mathrm{Ca}^{2+}$ fluxes in etiolated wildtype and phototropin-mutant Arabidopsis seedlings. Proceedings of the National Academy of Sciences 99(4): 2433-2438. DOI: 10.1073/pnas.042294599.

Bagri D.S., Upadhyaya D.C., Kumar A., Upadhyaya C.P. 2018. Overexpression of $P D X-I I$ gene in potato (Solanum tuberosum L.) leads to the enhanced accumulation of vitamin B6 in tuber tissues and tolerance to abiotic stresses. Plant Science 272: 267-275. DOI: 10.1016/j.plantsci.2018.04.024.

Bradford M.M. 1976. A rapid and sensitive method for the quantitation of microgram quantities of protein utilizing the principle of protein-dye binding. Analytical Biochemistry 72(1-2): 248-254. DOI: 10.1016/0003-2697(76)90527-3.

Carrera E., Jackson S.D., Prat S. 1999. Feedback control and diurnal regulation of gibberellin 20-oxidase transcript levels in potato. Plant Physiology 119(2): 765-774. DOI: 10.1104/pp.119.2.765.

Chen L., Xue X., Yang Y., Chen F., Zhao J., Wang X. et al. 2018. Effects of red and blue LEDs on in vitro growth and microtuberization of potato single-node cuttings. Frontiers of Agricultural Science and Engineering 5: 197-205. DOI: 10.15302/j-fase-2018224.

Chen L.L., Zhang K., Gong X.C., Wang H.Y., Gao Y.H., Wang X.Q. et al. 2020. Effects of different LEDs light spectrum on the growth, leaf anatomy, and chloroplast ultrastructure of potato plantlets in vitro and minituber production after transplanting in the greenhouse. Journal of Integrative Agriculture 19(1): 108-119. DOI: 10.1016/s2095-3119(19)62633-x.

Ciha A.J., Brun W.A. 1978. Effect of pod removal on nonstructural carbohydrate concentration in soybean tissue. Crop Science 18(5): 773-776. DOI: 10.2135/cropsci1978.0011183x001800050020x.
Cope K.R., Snowden M.C., Bugbee B. 2014. Photobiological interactions of blue light and photosynthetic photon flux: Effects of monochromatic and broadspectrum light sources. Photochemistry and Photobiology 90(3): 574-584. DOI: 10.1111/php.12233.

Dubois M., Gilles K.A., Hamilton J.K., Rebers P.A., Smith F. 1956. Colorimetric method for determination of sugars and related substances. Analytical Chemistry 28(3): 350-356. DOI: 10.1021/ac60111a017.

Felker F.C., Doehlert D.C., Eskins K. 1995. Effects of red and blue light on the composition and morphology of maize kernels grown in vitro. Plant Cell, Tissue and Organ Culture 42(2): 147-152. DOI: 10.1007/bf00034231.

Fixen K.R., Thomas S.C., Tong C.B.S. 2012. Blue light inhibition of tuberization in a day-neutral potato. Journal of Plant Growth Regulation 31(3): 342-350. DOI: 10.1007/s00344-011-9242-8.

Gökmen V., Bahçeci S., Acar J. 2002. Characterization of crude lipoxygenase extract from green pea using a modified spectrophotometric method. European Food Research and Technology 215(1): 42-45. DOI: 10.1007/s00217-002-0518-x.

Grant J.J., Yun B.W., Loake G.J. 2000. Oxidative burst and cognate redox signalling reported by luciferase imaging: identification of a signal network that functions independently of ethylene, SA and Me-JA but is dependent on MAPKK activity. Plant Journal 24(5): 569-582. DOI: 10.1046/j.1365-313x.2000.00902.x.

Halterman D., Guenthner J., Collinge S., Butler N., Douches D. 2016. Biotech potatoes in the 21st century: 20 years since the first biotech potato. American Journal of Potato Research 93(1): 1-20. DOI: 10.1007/s12230-015-9485-1.

Harada A., Sakai T., Okada K. 2003. Phot1 and phot2 mediate blue light-induced transient increases in cytosolic $\mathrm{Ca}^{2+}$ differently in Arabidopsis leaves. Proceedings of the National Academy of Sciences 100(14): 8583-8588. DOI: 10.1073/pnas.1336802100.

Harada A., Shimazaki K.I. 2007. Phototropins and blue light-dependent calcium signaling in higher plants. Photochemistry and Photobiology 83(1): 102-111. DOI: 10.1562/2006-03-08-ir-837.

Huché-Thélier L., Crespel L., Le Gourrierec J., Morel P., Sakr S., Leduc N. 2016. Light signaling and plant responses to blue and UV radiations - Perspectives for applications in horticulture. Environmental and Experimental Botany 121: 22-38. DOI: 10.1016/j.envexpbot.2015.06.009. 
Jackson S.D. 1999. Multiple signaling pathways control tuber induction in potato. Plant Physiology 119(1): 1-8. DOI: 10.1104/pp.119.1.1.

Jackson S.D., Willmitzer L. 1994. Jasmonic acid spraying does not induce tuberisation in short-day-requiring potato species kept in non-inducing conditions. Planta 194: 155-159. DOI: 10.1007/bf00196383.

Jena P.K., Reddy A.S.N., Poovaiah B.W. 1989. Molecular cloning and sequencing of a cDNA for plant calmodulin: Signal-induced changes in the expression of calmodulin. Proceedings of the National Academy of Sciences 86(10): 3644-3648. DOI: 10.1073/pnas.86.10.3644.

Kang G., Liu G., Peng X., Wei L., Wang C., Zhu Y. et al. 2013. Increasing the starch content and grain weight of common wheat by overexpression of the cytosolic AGPase large subunit gene. Plant Physiology and Biochemistry 73: 93-98. DOI: 10.1016/j.plaphy.2013.09.003.

Khan M.N., Mohammad F., Mobin M., Saqib M.A. 2014. Tolerance of plants to abiotic stress: a role of nitric oxide and calcium. In: Khan M.N., Mobin M., Mohammad F., Corpas F.J. (Eds.), Nitric oxide in plants: Metabolism and role in stress physiology. Springer, p. 225-242. DOI: 10.1007/978-3-319-06710-0_14.

Kobayashi M., Kawakita K., Maeshima M., Doke N., Yoshioka H. 2006. Subcellular localization of Strboh proteins and NADPH-dependent $\mathrm{O}_{2}^{-}$-generating activity in potato tuber tissues. Journal of Experimental Botany 57(6): 1373-1379. DOI: 10.1093/jxb/erj113.

Koda Y. 1997. Possible involvement of jasmonates in various morphogenic events. Physiologia Plantarum 100(3): 639-646. DOI: 10.1111/j.13993054.1997.tb03070.x.

Kolomiets M.V., Hannapel D.J., Chen H., Tymeson M., Gladon R.J. 2001. Lipoxygenase is involved in the control of potato tuber development. The Plant Cell 13(3): 613-626. DOI: 10.1105/tpc.13.3.613.

Kowallik W. 1982. Blue light effects on respiration. Annual Review of Plant Physiology 33(1): 51-72. DOI: 10.1146/annurev.pp.33.060182.000411.

Kurilčik A., Miklušytė-Čanova R., Dapkūnienè S., Žilinskaitè S., Kurilčik G., Tamulaitis G. et al. 2008. In vitro culture of Chrysanthemum plantlets using lightemitting diodes. Central European Journal of Biology 3(2): 161-167. DOI: 10.2478/s11535-008-0006-9.
Li C.-X., Xu Z.-G., Dong R.-Q., Chang S.-X., Wang L.Z., Khalil-Ur-Rehman M., Tao J.-M. 2017. An RNA-seq analysis of grape plantlets grown in vitro reveals different responses to blue, green, red LED light, and white fluorescent light. Frontiers in Plant Science 8; 78; 16 p. DOI: 10.3389/fpls.2017.00078

Li R., Huang W., Wang X., Liu X., Xu Z. 2018. Effects of yellow, green, and different blue spectra on growth of potato plantlets in vitro. HortScience 53(4): 541-546. DOI: 10.21273/hortsci12848-18.

Li R., Long J., Yan Y., Luo J., Xu Z., Liu X. 2020. Addition of white light to monochromatic red and blue lights alters the formation, growth, and dormancy of in vitrogrown Solanum tuberosum L. microtubers. HortScience 55(1): 71-77. DOI: 10.21273/hortsci14548-19.

Maccarrone M., Van Zadelhoff G., Veldink G.A., Vliegenthart J.F.G., Finazzi-Agrò A. 2000. Early activation of lipoxygenase in lentil (Lens culinaris) root protoplasts by oxidative stress induces programmed cell death. European Journal of Biochemistry 267(16): 5078-5084. DOI: 10.1046/j.1432-1327.2000.01564.x.

MacIntosh G.C., Ulloa R.M., Raíces M., Téllez-Iñón M.T. 1996. Changes in calcium-dependent protein kinase activity during in vitro tuberization in potato. Plant Physiology 112(4): 1541-1550. DOI: 10.1104/pp.112.4.1541.

Malone J.G., Mittova V., Ratcliffe R.G., Kruger N.J. 2006. The response of carbohydrate metabolism in potato tubers to low temperature. Plant and Cell Physiology 47(9): 1309-1322. DOI: 10.1093/pcp/pcj101.

Matsuo S., Nanya K., Imanishi S., Honda I., Goto E. 2019. Effects of blue and red lights on gibberellin metabolism in tomato seedlings. Horticulture Journal 88(1): 76-82. DOI: 10.2503/hortj.utd-005.

Milinkovic M., Horstra C.B., Rodoni B.C., Nicolas M.E. 2012. Effects of age and pretreatment of tissue-cultured potato plants on subsequent minituber production. Potato Research 55(1): 15-25. DOI: 10.1007/s11540-011-9203-4.

Murashige T., Skoog F. 1962. A revised medium for rapid growth and bio assays with tobacco tissue cultures. Physiologia Plantarum 15(3): 473-497. DOI: 10.1111/j.1399-3054.1962.tb08052.x.

Nam K.-H., Kong F., Matsuura H., Takahashi K., Nabeta K., Yoshihara T. 2008. Temperature regulates tuberinducing lipoxygenase-derived metabolites in potato (Solanum tuberosum). Journal of Plant Physiology 165(2): 233-238. DOI: 10.1016/j.jplph.2007.04.003. 
Nam K.-H., Minami C., Kong F., Matsuura H., Takahashi K., Yoshihara T. 2005. Relation between environmental factors and the LOX activities upon potato tuber formation and flower-bud formation in morning glory. Plant Growth Regulation 46(3): 253-260. DOI: $10.1007 / \mathrm{s} 10725-005-0056-1$.

Park S.W., Jeon J.H., Kim H.S., Hong S.J., Aswath C., Joung H. 2009. The effect of size and quality of potato microtubers on quality of seed potatoes in the cultivar 'Superior'. Scientia Horticulturae 120(1): 127-129. DOI: 10.1016/j.scienta.2008.09.004.

Pelacho A.M., Mingo-Castel A.M. 1991. Jasmonic acid induces tuberization of potato stolons cultured in vitro. Plant Physiology 97(3): 1253-1255. DOI: 10.1104/pp.97.3.1253.

Pinsky A., Grossman S., Trop M. 1971. Lipoxygenase content and antioxidant activity of some fruits and vegetables. Journal of Food Science 36(4): 571572. DOI: 10.1111/j.1365-2621.1971.tb15131.x.

Raíces M., Chico J.M., Téllez-Iñón M.T., Ulloa R.M. 2001. Molecular characterization of StCDPK1, a calcium-dependent protein kinase from Solanum tuberosum that is induced at the onset of tuber development. Plant Molecular Biology 46(5): 591601. DOI: 10.1023/a:1010661304980.

Raíces M., Ulloa R.M., MacIntosh G.C., Crespi M., Téllez-Iñón M.T. 2003. StCDPK1 is expressed in potato stolon tips and is induced by high sucrose concentration. Journal of Experimental Botany 54(392): 2589-2591. DOI: 10.1093/jxb/erg282.

Russell A.J., Cove D.J., Trewavas A.J., Wang T.L. 1998. Blue light but not red light induces a calcium transient in the moss Physcomitrella patens (Hedw.) B., S. \& G. Planta 206(2): 278-283. DOI: 10.1007/s004250050401.

Sadasivam S., Manickam A. 1992. Biochemical methods for agricultural sciences. Wiley Eastern, New Delhi, India, $246 \mathrm{p}$.

Sambrook J., Fritsch E.F., Maniatis T. 1989. Molecular cloning: A laboratory manual, second edition. Cold Spring Harbor Laboratory Press, USA.

Sarkar D. 2008. The signal transduction pathways controlling in planta tuberization in potato: an emerging synthesis. Plant Cell Reports 27(1): 1-8. DOI: 10.1007/s00299-007-0457-x.

Schuerger A.C., Brown C.S., Stryjewski E.C. 1997. Anatomical features of pepper plants (Capsicum annuиm L.) grown under red light-emitting diodes supplemented with blue or far-red light. Annals of Botany 79(3): 273-282. DOI: 10.1006/anbo.1996.0341.

Seabrook J.E.A. 2005. Light effects on the growth and morphogenesis of potato (Solanum tuberosum) in vitro: A review. American Journal of Potato Research 82(5): 353-367. DOI: 10.1007/bf02871966.

Seabrook J.E.A., Percy J.E., Douglass L.K., Tai G.C.C. 1995. Photoperiod in vitro affects subsequent yield of greenhouse-grown potato tubers. American Potato Journal 72(6): 365-373. DOI: 10.1007/bf02849333.

Smith H. 1994. Sensing the light environment: the functions of the phytochrome family. In: Kendrick R.E., Kronenberg G.H.M. (Eds.), Photomorphogenesis in plants, second edition. Springer, pp. 377-416. DOI: 10.1007/978-94-011-1884-2_15.

Stoelzle S., Kagawa T., Wada M., Hedrich R., Dietrich P. 2003. Blue light activates calcium-permeable channels in Arabidopsis mesophyll cells via the phototropin signaling pathway. Proceedings of the National Academy of Sciences 100(3): 1456-1461. DOI: 10.1073/pnas.0333408100.

Tadesse M., Lommen W.J.M., Struik P.C. 2001. Effects of temperature pre-treatment of transplants from in vitro produced potato plantlets on transplant growth and yield in the field. Potato Research 44(2): 173185. DOI: $10.1007 / \mathrm{bf02410104.}$

Tuteja N., Mahajan S. 2007. Calcium signaling network in plants. An overview. Plant Signaling and Behavior 2(2): 79-85. DOI: 10.4161/psb.2.2.4176.

Upadhyaya C.P., Bagri D.S., Upadhyaya D.C., Pathak A.K., Kawar P.G. 2016. Molecular and biochemical analysis of supplementation of calcium under in vitro condition on tuberization in potato (Solanum tuberosum L.). Biocatalysis and Agricultural Biotechnology 7: 210-216. DOI: 10.1016/j.bcab.2016.06.004.

Upadhyaya C.P., Gururani M.A., Prasad R., Verma A. 2013. A cell wall extract from Piriformospora indica promotes tuberization in potato (Solanum tuberosum L.) via enhanced expression of $\mathrm{Ca}^{+2}$ signaling pathway and lipoxygenase gene. Applied Biochemistry and Biotechnology 170(4): 743-755. DOI: 10.1007/s12010-013-0231-1.

Xu X., van Lammeren A.A.M., Vermeer E., Vreugdenhil D. 1998. The role of gibberellin, abscisic acid, and sucrose in the regulation of potato tuber formation in vitro. Plant Physiology 117(2): 575-584. DOI: 10.1104/pp.117.2.575. 